\title{
Non-Alkaloid Cholinesterase Inhibitory Compounds from Natural Sources
}

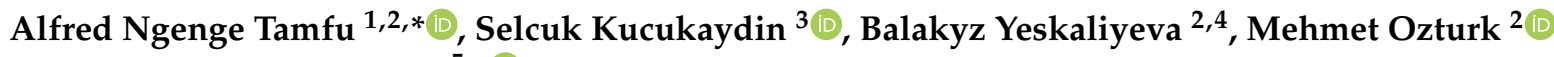 \\ and Rodica Mihaela Dinica $5, *$ (D)
}

1 School of Chemical Engineering and Mineral Industries, University of Ngaoundere, 454 Ngaoundere, Cameroon

2 Department of Chemistry, Mugla Sitki Kocman University, Mugla 48000, Turkey; balakyzyes@gmail.com (B.Y.); mehmetozturk@mu.edu.tr (M.O.)

3 Department of Medical Services and Techniques, Koycegiz Vocational School of Health Services, Mugla Sitki Kocman University, Mugla 48800, Turkey; selcukkucukaydin@gmail.com

4 Faculty of Chemistry and Chemical Technology, Al-Farabi Kazakh National University, Almaty 050040, Kazakhstan

5 Department of Chemistry, Physics and Environment, Faculty of Sciences and Environment, Dunarea de Jos University, 47 Domneasca Str., 800008 Galati, Romania

* Correspondence: macntamfu@yahoo.co.uk (A.N.T.); rodica.dinica@ugal.ro (R.M.D.); Tel.: +237-675590353 (A.N.T.); +33-6130-251 (R.M.D.)

Citation: Tamfu, A.N.;

Kucukaydin, S.; Yeskaliyeva, B.; Ozturk, M.; Dinica, R.M.

Non-Alkaloid Cholinesterase Inhibitory Compounds from Natural Sources. Molecules 2021, 26, 5582. https://doi.org/10.3390/molecules26185582

Academic Editors: Fengqing Yang, Jianbo Wan and Liya Ge

Received: 23 August 2021

Accepted: 10 September 2021

Published: 14 September 2021

Publisher's Note: MDPI stays neutral with regard to jurisdictional claims in published maps and institutional affiliations.

Copyright: (c) 2021 by the authors. Licensee MDPI, Basel, Switzerland. This article is an open access article distributed under the terms and conditions of the Creative Commons Attribution (CC BY) license (https:// creativecommons.org/licenses/by/ $4.0 /)$.
Abstract: Alzheimer's disease (AD) is a severe neurodegenerative disorder of different brain regions accompanied by distresses and affecting more than 25 million people in the world. This progressive brain deterioration affects the central nervous system and has negative impacts on a patient's daily activities such as memory impairment. The most important challenge concerning AD is the development of new drugs for long-term treatment or prevention, with lesser side effects and greater efficiency as cholinesterases inhibitors and the ability to remove amyloid-beta(A $\beta$ ) deposits and other related AD neuropathologies. Natural sources provide promising alternatives to synthetic cholinesterase inhibitors and many have been reported for alkaloids while neglecting other classes with potential cholinesterase inhibition. This review summarizes information about the therapeutic potential of small natural molecules from medicinal herbs, belonging to terpenoids, coumarins, and phenolic compounds, and others, which have gained special attention due to their specific modes of action and their advantages of low toxicity and high efficiency in the treatment of AD. Some show superior drug-like features in comparison to synthetic cholinesterase inhibitors. We expect that the listed phytoconstituents in this review will serve as promising tools and chemical scaffolds for the discovery of new potent therapeutic leads for the amelioration and treatment of Alzheimer's disease.

Keywords: Alzheimer's disease; cholinesterase inhibitors; terpenoids; phenolic compounds; coumarins

\section{Introduction}

The research of novel drug candidates has shown that natural products such as plant extracts and plant-originated compounds have enormous potential to become drug leads with neuroprotective activity. Several non-alkaloid phytochemicals have been obtained from natural sources, including terpenoids, coumarins, flavonoids, and other phenolic compounds which have beneficial neuroprotective properties particularly in cholinesterase inhibition hence, they are potential drug candidates for the treatment of Alzheimer's disease (AD). Alzheimer's disease (AD), one of the leading causes of dementia, is an overwhelming neurodegenerative disease that particularly affects brain function, resulting in memory loss and impairment of language, emotional disturbance, personality changes, depression, behavioral problems, and judgment capacity [1,2]. Besides dementia, it is a major cause of death amongst old people. In the brains of Alzheimer's disease (AD) patients, key neuropathological features of pathological protein deposits such as insoluble 
amyloid- $\beta$ (A $\beta$ peptides which form senile plaques) and hyperphosphorylated tau (which aggregates into NFTs) have been revealed [3]. It was reported that 35.6 million individuals suffered from AD in 2010, over 44 million people had dementia in 2013, and that the number will increase regularly to around 115 to 135 million individuals by $2050[4,5]$. The major physiological evidence of AD involves the degradation of cholinergic neurons and reduction in acetylcholine.

Cholinergic neurotransmission is terminated by two cholinesterases acetylcholinesterase (AChE) and butyrylcholinesterase (BChE), which play an essential role in the hydrolysis of ACh [6]. According to the cholinergic hypothesis, memory impairment in Alzheimer's disease is due to the deficit of cholinergic function in the brain, thereby, reducing hippocampal and cortical levels of the neurotransmitter acetylcholine (ACh) and associated enzyme choline transferase $[7,8]$. In the healthy brain, acetylcholinesterase (AChE) is the most important enzyme regulating the level of $\mathrm{ACh}$, while butyrylcholinesterase $(\mathrm{BChE})$ plays a minor role [1]. It is therefore expected that if the hydrolysis of $\mathrm{ACh}$ by $\mathrm{AChE}$ and $\mathrm{BChE}$ is inhibited in the brain of an $\mathrm{AD}$ patient, the amount of $\mathrm{ACh}$ in the synapse will be significantly increased and the neurotransmission mechanism will be more fluid [9]. For this reason, acetylcholinesterase $(\mathrm{AChE})$ and butyrylcholinesterase $(\mathrm{BuChE})$ inhibitors such as galantamine, donepezil, and rivastigmine are used in the management of $\mathrm{AD}$, and the inhibition of the two types of cholinesterase enzymes ( $\mathrm{AChE}$ and $\mathrm{BuChE}$ ) as remedial for such treatment [10]. However, the high cost, non-selectivity, limited efficacy, poor bioavailability, and adverse cholinergic side effects in the periphery, such as nausea, vomiting, diarrhea, dizziness, gastro-intestinal disorders, moderate to low effectiveness, short half-life, and hepatotoxicity are the several limitations of these drugs [11]. These reasons have prompted the search for newer molecules from natural products by researchers worldwide because cholinesterase inhibitors are known to occur in plants used traditionally for failing memory and other cognitive declines associated with age [12]. For example, galantamine, physostigmine, and huperzine A have been isolated from Galanthus nivalis, Physostigma venenosum, and Huperzia serrata, respectively, and clinically used for AD symptomatic management [13].

Alkaloids include a high number of compounds with anticholinesterases, though some terpenes, coumarins, and lignans have been shown to have this activity. Recently, research has targeted alkaloid compounds as potent anticholinesterase compounds and little attention has been given to other classes. In this review, we report a representative update of terpenoids, phenolic, and coumarin compounds with their AChE and $\mathrm{BChE}$ inhibitory potentials according to reports from 2009 to 2021.

\section{Natural Non-Alkaloid Cholinesterase Inhibitors}

Alzheimer's disease (AD) is the most common form of dementia mostly in old people, characterized by low acetylcholine levels and oxidative stress, involving progressive neurodegeneration with the formation of amyloid- $\beta$ deposits in the brain. The number of individuals suffering from this disease and its related neuropathologies has been increasing over the years and a majority of the patients are old people. A proper strategy to overcome $\mathrm{AD}$ is by the inhibition of cholinesterase enzymes which helps to increase acetylcholine levels in the brain which is necessary for neurotransmission, memory, reasoning, and other cognitive activities. Though synthetic cholinesterase inhibitors, including rivastigmine, donepezil, and galantamine are usually employed as a remedy to $\mathrm{AD}$, there is a growing interest in the search for new cholinesterase inhibitors from natural sources due to the drawbacks of synthetic ones, and most non-alkaloid natural anticholinesterase compounds are terpenoids, phenolic compounds, and coumarins, amongst others.

The Supplementary Material (Tables S1-S4) gives the representative non-alkaloid naturally occurring compounds with useful anticholinesterase properties obtained mainly from plants as summarized below (Figure 1). Figure 1 gives a vivid indication of sources of starting material for cholinesterase inhibitory compounds and drugs. The compounds obtained from these plants have been explored to target pathological features in neurode- 
generative diseases such as $\mathrm{AD}$ and can be also used as a starting point to design a new library of potent derivatives.

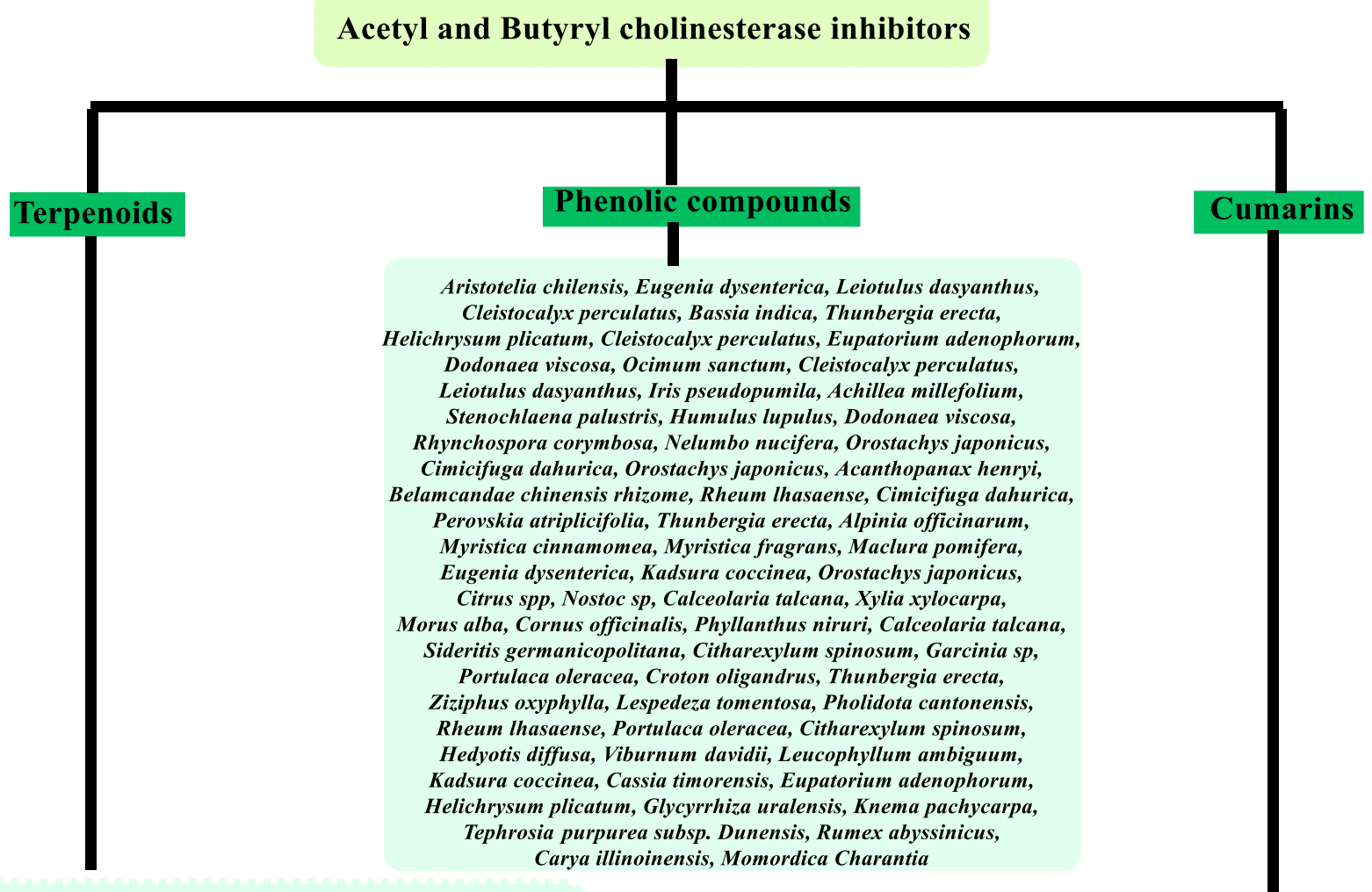

Salvia austriaca, Caryopteris mongolica, Perovskia atriplicifolia, Salvi.a glutinosa, Nelumbo nucifera, Cimicifuga dahurica,

Xylia xylocarpa, Garcinia hombroniana, Rhynchospora corymbose, Pimpinella anisoides, Cynara cornigera, Amberboa ramosa,

Inula spp, Maytenus disticha, Euonymus japonicus,

Calceolaria talcana, Portulaca oleracea Grewia optiva,

Tinospora cordifolia, Sideritis germanicopolitana, Celtis adolphi-friderici,

Bassia indica, Citharexylum spinosum, Hedyotis diffusa,

Rhodomyrtus tomentosa, Paecilomyces sp, Kadsura coccinea, Cupressus macrocarpa, Cipadessa baccifera
Mutellina purpurea, Caryopteris odorata, Angelica archangelica, Caryopteris odorata, Heptaptera cilicica, Angelica officinalis, Angelica purpurascens, Leiotulus dasyanthus,

Portulaca oleracea, Croton oligandrus, Argyreia speciosa, Bassia indica, Ferula pseudalliacea, Peucedanum japonicum,

Figure 1. Non-alkaloid cholinesterases inhibitors and their natural sources.

\section{Discussion}

\subsection{Terpenoids}

Several terpenoids from natural sources have been reported as cholinesterase inhibitors [14-42]. The compounds 1-11, as shown in Supplementary Material (Table S1), are of the Abietane-type diterpene skeletons isolated from Salvia austriaca, Salvia glutinosa, Caryopteris mongolica, and Perovskia atriplicifolia [14-16]. Between compounds 2-7, there is an -OH group on the side chain, except for compound 5 which has a methoxy $\left(\mathrm{CH}_{3} \mathrm{O}-\right)$ group on the side chain and has the highest $\mathrm{AChE}$ inhibition activity. The high activity could be due to the presence of this methoxy group. In the same way, compound 2 has good activity and possesses a methoxy group on ring $C$ and has an $\mathrm{IC}_{50}$ of $27.9 \pm 5.2 \mu \mathrm{M}$ compared to compound 5 with an $\mathrm{IC}_{50}$ of $20.8 \pm 7.1 \mu \mathrm{M}$. Compounds 8 to $\mathbf{1 1}$ are miltirone derivatives though with little structural differences, there is no significant difference in their cholinesterase inhibition activity. Compounds 12-19 are tanshinone derivatives [16]. Compounds $\mathbf{1 6}$ and $\mathbf{1 7}$ are the most active with percentage inhibitions of $6.19 \pm 3.91 \%$ and $5.55 \pm 3.03 \%$, respectively at $10 \mu \mathrm{g} / \mathrm{mL}$. This could be attributed to the conjugated double bond system in ring A which is particular to these two compounds. Compound 20, a monoterpene glycoside nuciferoside, shows very high activity with an $\mathrm{IC}_{50}$ value of $3.20 \pm 0.22 \mu \mathrm{M}$ [17]. Compounds 21-36 are cycloartanes triterpenoids iso- 
lated from Cimicifuga dahurica and Nelumbo nucifera $[17,18]$. Amongst them, compound 25 is the most active with a percentage inhibition of $15.8 \pm 4.3 \%$ and $14.0 \pm 2.6 \%$ on $\mathrm{AChE}$ and BChE, respectively, at $100 \mu \mathrm{M}$. This could possibly be attributed to the absence of the double bond in ring $B$ of this compound. Compounds 37-42 are lupane type triterpenoids isolated from Garcinia hombroniana and Xylia xylocarpa and they show relatively low activities $[19,20]$. The oleanane triterpenoids 43,44 , and 45 isolated from Xylia xylocarpa and Rhynchospora corymbose show low activities [19,21]. The sterols 46 and 47 from Rhynchospora corymbose show low activities as well as the monoterpenes 48 , 49, and 50 from Pimpinella anisoides [21,22]. Sesquiterpene lactones from 51-64 isolated from Inula spp., Cynara cornigera, and Amberboa ramosa show good anticholinesterase activities [23-25]. Compounds 58-61 are amberbin C, amberin, amberbin A, and amberbin B, and have high anticholinesterase activity [24]. Amongst them, those possessing sugar moieties, amberin ( $\mathrm{IC}_{50} 17.5 \pm 0.01 \mu \mathrm{M}$ and $2.7 \pm 0.02 \mu \mathrm{M}$ for $\mathrm{AChE}$ and $\mathrm{BChE}$, respectively) and amberin $\mathrm{B}\left(\mathrm{IC}_{50} 0.91 \pm 0.015 \mu \mathrm{M}\right.$ and $2.5 \pm 0.15 \mu \mathrm{M}$ for $\mathrm{AChE}$ and $\mathrm{BChE}$, respectively) are the most active and the structural difference between them is the interchange of the positions of an acetyl group and sugar moiety. The agarofuran derivatives 62-73 isolated from Euonymus japonicus and Maytenus disticha have low activities [25,26]. The taraxaranes 74,75 , and 76, oleananes 77,78, and 79, as well as the ursane tritepenoids 80 and 81 , have relatively low activities except for compound 74 with $\mathrm{IC}_{50}$ values of $13.5 \pm 0.95 \mu \mathrm{M}$ and $10.6 \pm 0.54 \mu \mathrm{M}$ on AChE and BChE inhibitions $[20,27,28]$. Its relatively high activity could be attributed to the presence of the caffeoyl group at position 3. It can be concluded that amongst the terpenoids, sesquiterpenes are the most active compounds, especially sesquiterpene lactones.

\subsection{Phenolic Compounds}

Phenolic compounds from natural sources have shown anticholinesterase activity in several studies [34,43-84]. Phenolic compounds whose anticholinesterase activities have been reported are given in the Supplementary Material (Table S2). Compounds 1-19 are flavone derivatives with a double bond in ring $C$ and a carbonyl at position 4 [34,43-53]. There is no observable regular pattern of variation in activity. However, compounds with no hydroxyl group on position 3 show seemingly high cholinesterase inhibition activity, for example, compounds 4 and 5. However, compounds 16-19 do not have a hydroxyl group at position 3 but their activities are low and could be accounted for by the occurrence of methoxy groups on the other rings. There is an observable decrease in cholinesterase inhibition in flavones with methoxy substituents, for example, compounds 13 and 14, and compounds 7 and 8. This observation is not true for compounds 14 and 15 as 14 has a methoxy group on ring $B$ but is more active than 15 without a methoxy group. This could be due to the absence of a substituent on ring B of compound 15. Between cirsilineol (18) and isothymusin (19), an additional hydroxy group on ring A causes a decrease in cholinesterase inhibition. For the flavonoid glycosides, compounds 20-33 [43,45,46,49,50,54,55], those with a sugar moiety at position 7, have higher activities than the others, for example, 27, 28, and 29 isolated from Achillea millefolium. If the sugar has substituents, as is the case of 32 and 33, the activity is further reduced. Compounds 34 to 38, isolated from Dodonaea viscosa, have isoprenyl substituents but, however, show no significant difference in their activities [51]. Rather, their activities are lower than their corresponding compounds without isoprenyl substituents. Compounds 39-41 have acetyl groups and their BChE inhibitory activity decreases with an increase in the number of acetyl groups [21]. The phenolic acid compounds $42-45$, and compound 44 ferulic acid methyl ester have a good percentage of cholinesterase inhibition [17,18,57]. The presence of sugar substituents causes a decrease in cholinesterase inhibition as seen in compounds $\mathbf{4 6 - 4 8}$ [17,58], while an additional phenolic group causes an increase in cholinesterase inhibition as seen in compounds 49-64 [16,18,47,52,59-62]. Amongst the biphenyl compounds, 58, 59, 60, and $\mathbf{6 1}$ isolated from Myristica cinnamomea have high activity, and in these compounds, the carbonyl function is adjacent to one of the phenyl groups (phenyl carbonyl). Isoflavones compounds 
65-79 isolated from Iris pseudopumila, Maclura pomifera, and Belamcandae chinensis rhizoma have low activities $[52,54,59,63]$. Amongst them, methoxy substituents cause no significant change in cholinesterase inhibition while the presence of sugar molecules causes a decrease in this activity. For those with prenyl groups (75-79) isolated from Maclura pomifera, there was no observable effect due to the presence of the prenyls, but an - $\mathrm{OH}$ group on ring $\mathrm{B}$ caused an increase in activity between compounds 75 and 76. Catechin and its derivatives $\mathbf{7 9}$ to $\mathbf{8 4}$ isolated from Eugenia dysenterica and Orostachys japonicus had no good activity and no significant difference despite structural differences except between compound $\mathbf{8 2}$ and $\mathbf{8 3}$ where the additional benzoic acid substituent increased AChE and BChE inhibition activities [40,44,57]. This observation was similar for the flavanones 85 to 89 , though the addition of sugar molecules caused an increase in AChE and BChE inhibitions in compound 90 compared to compound $85[50,51,56,64]$. The xanthones compound 95-101 isolated from Garcinia mangostana and Belamcandae chinensis rhizoma showed moderate to good AChE and BChE inhibition activities $[19,66,67]$. Evidently, an increase in the hydroxyl groups causes an increase in the cholinesterase inhibitory activity of these xanthones, while no significant difference in cholinesterase inhibition is observed for the prenyl groups. For the chalcones $\mathbf{1 0 2}$ to $\mathbf{1 0 5}$ isolated from Humulus lupulus, the activity decreases from compound 102 to 105 with a decrease in the number of hydroxyl $(-\mathrm{OH})$ substituents [56]. Aurones 106-109 isolated from Morus alba have low activities though 109 had BChE inhibition with an $\mathrm{IC}_{50}$ of $7.22 \pm 0.22 \mu \mathrm{M}$ [68]. Amongst the tannin compounds 110 to 115, isolated from Cornus officinalis, Phyllanthus niruri, and Calceolaria talcana, compound 114 (Isocorilagin) is the most active with an $\mathrm{IC}_{50}$ of $0.49 \mu \mathrm{M}$ and $4.20 \mu \mathrm{M}$ on AChE and BChE inhibition, respectively $[28,32,36,69,70]$. This could be because it is less bulky, having only three benzoyl groups as compared to compounds 112 and 113 with five benzoyl groups and 110 and 111 with four benzoyl groups. The triflavanone Garcineflavanone A and biflavonol Garcineflavonol A isolated from Garcinia atroviridis both showed good percentage inhibition of cholinesterase. M. charantia extract showed many inhibitory activities, however, ligballinol a lignan found in extract showed relatively high activity. According to previous studies, not many lignans have been reported to exhibit cholinesterase inhibitory activity [85].

\subsection{Coumarins}

Coumarins constitute another important class of cholinesterase inhibitors as seen in some scientific reports [86-95]. Compounds 1-6 (Table S3) isolated from Angelica archangelica, Caryopteris odorata, and Mutellina purpurea showed low activities, and although with slight structural differences, there is no significant difference in their activities [86-89]. Between compounds 6 and 7, the addition of a prenyl group decreases the percentage inhibition. Compound 9, Umbelliprenin, isolated from Heptaptera cilicica, shows good activity with $\mathrm{IC}_{50}$ values of $5.86 \pm 0.030 \mu \mathrm{M}$ and $1.10 \pm 0.190 \mu \mathrm{M}$ on $\mathrm{AChE}$ and BChE inhibition $[90,91]$. By adding hydroxyl $(-\mathrm{OH})$, carboxyl $(-\mathrm{COOH})$, or acetyl substituent to compounds 10, 11, and 12, respectively, the percentage inhibitions increase as compared to compound 7 [90]. Subsequent addition of isoprenyl groups, as seen in compounds 13 and 14, decreases the percentage cholinesterase inhibition [90]. This effect is illustrated with compounds 15 and $\mathbf{1 6}$ in which addition of one isoprenyl group to compound 15 to obtain 16 decreases AChE percentage inhibition from $11.47 \pm 1.73 \%$ to $7.03 \pm 2.08 \%$ and also between compound $\mathbf{1 7}$ and 19 where the addition of one isoprenyl decrease BChE inhibition from $51.04 \pm 1.88 \%$ to $23.82 \pm 2.41 \%$ [90]. For di-o prenylated coumarins, 22 with two $O$-geranyl groups and 23 with two $O$-farnesyl groups, 23 shows a higher percentage inhibition than 22 , and this could be attributed to the additional isoprene unit in 23 [90]. For the coumarins 24 to 32, the only structural difference is on the side chain and this causes a significant difference in the cholinesterase inhibition activity of the corresponding compounds [90]. For these compounds, unsaturation in the side chain caused no significant change in the cholinesterase inhibition activity. However, compound 26 having a styryloxy group has the highest $\mathrm{AChE}$ inhibition percentage while compound 30 with the isobutyloxy group has the highest $\mathrm{BChE}$ inhibition activity. Compounds 33 to 
41, isolated from Angelica officinalis, Leiotulus dasyanthus, and Angelica archangelica, did not show significant activity $[45,88,89,92]$. The umbelliferone and its derivatives, compounds 42 to 46 isolated from Angelica archangelica, Leiotulus dasyanthus, and Heptaptera cilicica, showed good activity $[45,88,91]$. The most active umbelliferone derivatives were conferone ( $\mathrm{IC}_{50} 3.31 \pm 0.014 \mu \mathrm{M}$ and $9.31 \pm 0.280 \mu \mathrm{M}$ on $\mathrm{AChE}$ and $\mathrm{BChE}$ respectively), mogoltacin ( $\mathrm{IC}_{50} 1.95 \pm 0.050 \mu \mathrm{M}$ and $9.74 \pm 0.003 \mu \mathrm{M}$ on $\mathrm{AChE}$ and BChE respectively), and feselol ( $\mathrm{IC}_{50} 1.26 \pm 0.010 \mu \mathrm{M}$ and $9.98 \pm 0.240 \mu \mathrm{M}$ on $\mathrm{AChE}$ and $\mathrm{BChE}$ respectively) and were all isolated from Heptaptera cilicica. It can be concluded that, in the class of coumarins, umbelliferone derivatives are the most potent cholinesterase inhibitory compounds.

Other miscellenous compounds (Table S4) have equally shown interesting acetylcholinesterase and butyrylcholinesterase inhibitory activities [96-116].

\subsection{Some Considerations on Terpenoids, Phenolic Compounds, and Coumarins as Cholinesterase Inhibitors}

It is important to search for new therapies which are more effective than those currently existing, and which can both prevent neurodegenerative diseases such as $\mathrm{AD}$ and block the progression of these pathologies at their early stages, thereby reducing the socioeconomic costs involved in the management of $\mathrm{AD}$ and the patients [117]. Acetylcholine is a key neurotransmitter involved in cognitive activities, but its activity can be reduced by $\mathrm{AChE}$ and $\mathrm{BChE}$ which hydrolyze acetylcholine into choline and acetic acid causing the cholinergic neurotransmission to decrease. The development of many therapies for $\mathrm{AD}$ is based mainly on this cholinergic hypothesis, and the remediation of acetylcholine levels and cholinergic function in the central nervous system through the inhibition of cholinesterase enzymes ( $\mathrm{AChE}$ and $\mathrm{BChE}$ ) can eliminate the pathologies of $\mathrm{AD}$. The classes of cholinesterase inhibitors discussed here are mainly terpenoids, phenolic compounds, and coumarins, and some of these compounds have shown high potency. In order to consider which classes are most suitable, based on the benefits and drawbacks, certain structural features of each class will be of great importance. Using chalcones as an example, it is believed that besides economical and cost-effective production, small molecular size and flexibility for modifications to improve lipophilicity necessary for blood-brain barrier permeability are important to consider for a preferred potential therapeutic candidate for AD [118]. Terpenoids are able to inhibit cholinesterases in different ways. It has been shown that 1,8-cineole, $\alpha$-pinene, and camphor could inhibit AChE reversibly [119]. Certain tanshinone derivatives could be noncompetitive inhibitors of $\mathrm{AChE}$ and $\mathrm{BChE}$ in humans and are able to bind to the allosteric site of cholinesterases principally through hydrophobic interactions and also through hydrogen bonds with Tyr337 and Gly120 of AChE [120]. Carbonyl function in terpenes can bind by covalent arrangement to the free amino or sulfhydryl groups of the enzyme while phenolic hydroxyl groups bind proteins, leading to the conformational change of the enzyme [121]. Terpene alcohols and terpene hydrocarbon compounds possess identical cholinesterase inhibition while terpenoids with a ketone group exhibit stronger cholinesterase inhibition and an allylic group increases activity [121,122]. Amongst the terpenoids, monoterpenoids are the most promising because the inhibition of AChE has been shown to remedy AD by inhibiting amyloid-beta-induced neurotoxicity and also clearing it, tau-protein phosphorylation, and oxidative stress by boosting antioxidant defenses, neuroinflammation, restoration of mitochondrial function, initiation of processes with simultaneous inhibition of pro-apoptotic genes and proteins [123]. In the phenolic compounds, inhibitory activity is influenced by the position and number of hydroxyl and methoxyl groups bonded to the phenol ring, and the methoxy substitution on the phenol ring improves cholinesterase inhibitory activity and phenolic acids are capable of inhibiting the formation of amyloid $\beta$-peptide (A $\beta$ ) fibrils [124]. Phenolic compounds exert neuroprotective effects, though it is assumed that the transfer of polyphenols through the blood-brain barrier is limited, likewise, a considerable number of reports discuss the absorption and presence of phenolic acids in the brain [125]. Phenolic compounds are able to bind to the active sites of AChE or BChE resulting in the inhibition of these enzymes [126]. Aromatic ring moieties are suggested to 
be involved in the selection and stabilization of the positive charge of the quaternary group in the acetylcholine, and some of the flavonoids can induce modifications in the structure of cholinesterase enzymes blocking entrance into the active site and those with free $\mathrm{OH}$ groups are also more potent than glycosylated ones. Phenolic compounds structurally similar to caffeic acid are capable of fitting into the gorge of the active site of AChE and are more potent [127]. In coumarins, it has been shown that those with larger substituents at position 7 have a higher inhibitory effect than those with small substituent groups at the same position, and equally, compounds that contain a coumarin nucleus and a long-chain substituent with some phenyl and aryl/benzyl-piperazines groups can be more potent inhibitors of cholinesterase [128,129]. The anticholinesterase activity of coumarins is mostly dependent on their binding ability on the enzyme, and this activity is greatly improved in the scaffolds with some cholinesterase inhibitory drugs [129]. Moreover, the structure of coumarins is highly modifiable through chemical means, thereby presenting them as suitable starting materials for the synthesis of drugs. Many cholinesterase drugs with a coumarin nucleus have been reported, making coumarin a priority pharmacophore for cholinesterase inhibitors. In a study in which 36 isolated compounds were classified and discussed according to their anti-AChE pharmacological potency, phenolic compounds and flavonoids were mostly found in the low activity zone of natural acetylcholinesterase inhibitors according to their ability to bind to the active site of acetylcholinesterase [130]. Coumarins and terpenoids occupied zones indicated as moderate to high activity and capacity of binding to the active site of acetylcholinesterase [130].

However, preclinical, clinical safety, selectivity, and toxicity of these compounds are not established, and classification of these compounds based on their benefits and drawbacks will be controversial and non-conclusive. However, a common point seems to be the overall size of the compound which should generally be small so as to be able to cross the blood-brain barrier and exerts its function.

\section{Conclusions}

Neurodegenerative disease is a generic term applied to a variety of conditions arising from a chronic breakdown and deterioration of the central nervous system (CNS) neurons. Many of these diseases exist, but Alzheimer's disease (AD) is the most prevalent. Alzheimer's disease (AD) patients present a progressive loss of cholinergic synapses in the brain regions associated with a decrease in the acetylcholine (ACh), a neurotransmitter, which appears to be a critical element in the development of dementia. Hence, AD and other forms of dementia could be treated by the use of agents that restore the level of acetylcholine through the inhibition of both major forms of cholinesterase: acetylcholinesterase (AChE) and butyrylcholinesterase (BChE). Loizzo and co-workers postulated that $\mathrm{AD}$ causes and progression involves four relevant pathogenic events: primary events (genetic alterations, neuronal apoptosis-like processes leading to premature neuronal death and brain dysfunction), secondary events ( $\beta$-amyloid deposition in senile plaques and brain vessels, neurofibrillary tangles due to the hyperphosphorylation of tau proteins, synaptic loss), tertiary events (neurotransmitter deficits, neurotrophic alterations, neuroimmune dysfunction, neuroinflammatory processes), and quaternary events (accelerated neuronal death due to excitotoxic reactions, alterations in calcium homeostasis, free radical formation, cerebrovascular dysfunction) [117]. The potential use of natural products in the treatment of neurodegenerative disorders has also been successfully demonstrated in the field of $\mathrm{AD}$, and also to treat other forms of dementia including vascular dementia, Parkinson's dementia, dementia/Lewy body, and cognitive symptoms associated with multiple sclerosis and Down syndrome. However, much attention is focused on alkaloids while little is given to phenolics, terpenoids, and coumarins, and this review gives an update of representative non-alkaloid compounds with anticholinesterase activity. 
Supplementary Materials: The following are available as supplementary material online; Table S1: Terpenoids as Acetyl and Butyryl cholinesterase inhibitors, Table S2: Phenolic compounds as Acetyl and Butyryl cho-linesterase inhibitors, Table S3: Coumarins as Acetyl and Butyryl cholinesterase inhibitors and Table S4: Other Acetyl and Butyryl cholinesterase inhibitors.

Author Contributions: Conceptualization, A.N.T. and M.O.; methodology, A.N.T., S.K., B.Y., M.O. and R.M.D.; validation, resources and data curation, A.N.T., S.K., B.Y., M.O. and R.M.D.; writing-original draft preparation, A.N.T., S.K., B.Y., M.O. and R.M.D.; writing-review and editing, A.N.T., S.K., B.Y., M.O. and R.M.D.; visualization, A.N.T., S.K. and R.M.D.; supervision, M.O. and R.M.D.; funding acquisition, A.N.T., M.O. and R.M.D. All authors have read and agreed to the published version of the manuscript.

Funding: The authors are grateful for financial support from Turkiye Burslari Research Scholarship (19CM000746). The APC was funded by 'Dunarea de Jos University', Galati, Romania.

Institutional Review Board Statement: Not applicable.

Informed Consent Statement: Not applicable.

Acknowledgments: The authors are grateful for support from 'Dunarea de Jos University', Galati, Romania, Mugla Sitki Kocman University as well as to Turkiye Burslari and TUBITAK-BIDEP 2221 Fellowships for visitng scientists and scientists on sabbatical leave.

Conflicts of Interest: The authors declare no conflict of interest. The funders had no role in the design of the study; in the collection, analyses, or interpretation of data; in the writing of the manuscript, or in the decision to publish the results.

\section{References}

1. Ahmed, F.; Ghalib, R.M.; Sasikala, P.; Ahmed, K.K.M. Cholinesterase inhibitors from botanicals. Pharmacogn. Rev. 2013, 7, 121-130. [CrossRef] [PubMed]

2. Ali Reza, A.S.M.; Hossain, M.S.; Akhter, S.; Rahman, M.R.; Nasrin, M.S.; Uddin, M.J.; Sadik, G.; Khurshid Alam, A.H.M. In vitro antioxidant and cholinesterase inhibitory activities of Elatostema papillosum leaves and correlation with their phytochemical profiles: A study relevant to the treatment of Alzheimer's disease. BMC Complement. Altern. Med. 2018, 18, 123. [CrossRef] [PubMed]

3. Sharman, M.J.; Verdile, G.; Kirubakaran, S.; Parenti, C.; Singh, A.; Watt, G.; Karl, T.; Chang, D.; Li, C.C.; Münch, G. Targeting Inflammatory Pathways in Alzheimer's Disease: A Focus on Natural Products and Phytomedicines. CNS Drugs 2019, 33, 457-480. [CrossRef] [PubMed]

4. Prince, M.; Guerchet, M.; Prina, M. Policy Brief for Heads of Government: The Global Impact of Dementia 2013-2050. Available online: https:/ / www.alzint.org/resource/policy-brief-the-global-impact-of-dementia-2013-2050/ (accessed on 1 December 2013).

5. Abdelhameed, R.; Elgawish, M.S.; Mira, A.; Ibrahim, A.K.; Ahmed, S.A.; Shimizu, K.; Yamada, K. Anti-choline esterase activity of ceramides from the Red Sea Marine Sponge Mycale euplectellioides. RSC Adv. 2016, 6, 20422-20430. [CrossRef]

6. Giacobini, E. Cholinesterases: New roles in brain function and in Alzheimer's disease. Neurochem. Res. 2003, $28,515-522$. [CrossRef]

7. Bartus, B.T.; Dean, R.L.; Beer, B.; Lippa, A.S. The cholinergic hypothesis of geriatric memory dysfunction. Science 1982, 217, 408-417. [CrossRef]

8. Perry, E.K. The cholinergic hypothesis: Ten years on. Br. Med. Bull. 1986, 42, 63-69. [CrossRef]

9. Murakawa, T.; Matsushita, Y.; Suzuki, T.; Khan, M.T.; Kurita, N. Ab initio molecular simulations for proposing potent inhibitors to butyrylcholinesterase. J. Mol. Graph. Model. 2014, 54, 54-61. [CrossRef]

10. Tamfu, A.N.; Fotsing, M.T.; Talla, E.; Ozturk, M.; Mbafor, J.T.; Duru, M.E.; Shaheen, F. Chemical composition and evaluation of anticholinesterase activity of essential oil from Cameroonian propolis. Issues Biol. Sci. Pharml. Res. 2019, 7, 58-63.

11. Burns, A.; Iliffe, S. Alzheimer's disease. BMJ 2009, 338, 467-471. [CrossRef]

12. Howes, M.J.; Houghton, P.J. Plants used in Chinese and Indian Traditional Medicine for improvement of memory and cognitive function. Pharmacol. Biochem. Behav. 2003, 75, 513-527. [CrossRef]

13. Houghton, P.J.; Ren, Y.; Howes, M.J. Acetylcholinesterase inhibitors from plants and fungi. Nat. Prod. Rep. 2006, 23, 181-199. [CrossRef]

14. Kuźma, L.; Wysokińska, H.; Sikora, J.; Olszewska, P.; Mikiciuk-Olasik, E.; Szymański, P. Taxodione and extracts from Salvia austriaca roots as human cholinesterase inhibitors. Phytother. Res. 2016, 30, 234-242. [CrossRef]

15. Murata, T.; Ishikawa, Y.; Saruul, E.; Selenge, E.; Sasaki, K.; Umehara, K.; Yoshizaki, F.; Batkhuu, J. Abietane-type diterpenoids from the roots of Caryopteris mongolica and their cholinesterase inhibitory activities. Phytochemistry 2016, 130, 152-158. [CrossRef] 
16. Senol, F.S.; Slusarczyk, S.; Matkowski, A.; Perez-Garrido, A.; Giron-Rodríguez, F.; Ceron-Carrasco, J.P.; den-Haan, H.; Pena-García, J.; Perez-Sanchez, H.; Domaradzki, K.; et al. Selective in vitro and in silico butyrylcholinesterase inhibitory activity of diterpenes and rosmarinic acid isolated from Perovskia atriplicifolia Benth. and Salvia glutinosa L. Phytochemistry 2017, 133, 33-44. [CrossRef]

17. Jung, H.A.; Jung, Y.J.; Hyun, S.K.; Min, B.S.; Kim, D.W.; Jung, J.H.; Choi, J.S. Selective cholinesterase inhibitory activities of a new monoterpene diglycoside and other constituents from Nelumbo nucifera stamens. Biol. Pharm. Bull. 2010, 33, 267-272. [CrossRef] [PubMed]

18. Kim, J.H.; Thao, N.P.; Han, Y.K.; Lee, Y.S.; Luyen, B.T.T.; Oanh, H.V.; Kim, Y.H.; Yang, S.Y. The insight of in vitro and in silico studies on cholinesterase inhibitors from the roots of Cimicifuga dahurica (Turcz.) Maxim. J. Enzym. Inhib. Med. Chem. 2018, 33, 1174-1180. [CrossRef] [PubMed]

19. Lam, L.M.T.; Nguyen, M.T.T.; Nguyen, H.X.; Dang, P.H.; Nguyen, N.T.; Tran, H.M.; Nguyen, H.T.; Nguyen, N.M.; Min, B.S.; Kim, J.A.; et al. Anti-cholinesterases and memory improving effects of Vietnamese Xylia xylocarpa. Chem. Cent. J. 2016, 10, 48. [CrossRef]

20. Jamila, N.; Khairuddean, M.; Yeong, K.K.; Osman, H.; Murugaiyah, V. Cholinesterase inhibitory triterpenoids from the bark of Garcinia hombroniana. J. Enzym. Inhib. Med. Chem. 2015, 30, 133-139. [CrossRef]

21. Pagning, A.L.N.; Tamokou, J.-D.; Lateef, M.; Tapondjou, L.A.; Kuiate, J.-G.; Ngnokam, D.; Ali, M.S. New triterpene and new flavone glucoside from Rhynchospora corymbosa (Cyperaceae) with their antimicrobial, tyrosinase and butyrylcholinesterase inhibitory activities. Phytochem. Lett. 2016, 16, 121-128. [CrossRef]

22. Menichini, F.; Tundis, R.; Loizzo, M.R.; Bonesi, M.; Marrelli, M.; Statti, G.A.; Menichini, F.; Conforti, F. Acetylcholinesterase and butyrylcholinesterase inhibition of ethanolic extract and monoterpenes from Pimpinella anisoides V Brig. (Apiaceae). Fitoterapia 2009, 80, 297-300. [CrossRef]

23. Hegazy, M.E.F.; Ibrahim, A.Y.; Mohamed, T.A.; Shahat, A.A.; Halawany, A.M.E.; Abdel-Azim, N.S.; Alsaid, M.S.; Pare, P.W. Sesquiterpene Lactones from Cynara cornigera: Acetyl Cholinesterase Inhibition and In Silico Ligand Docking. Planta Med. 2016, 82, 138-146. [PubMed]

24. Ibrahim, M.; Farooq, T.; Hussain, N.; Hussain, A.; Gulzar, T.; Hussain, I.; Akash, M.S.; Rehmani, F.S. Acetyl and butyryl cholinesterase inhibitory sesquiterpene lactones from Amberboa Ramosa. Chem. Cent. J. 2013, 7, 116. [CrossRef] [PubMed]

25. Hajimehdipoor, H.; Mosaddegh, H.; Naghibi, F.; Haeri, A.; Hamzeloo-Moghadam, M. Natural sesquiterpene lactones as acetylcholinesterase inhibitors. Ann. Braz. Acad. Sci. 2014, 86, 801-805. [CrossRef] [PubMed]

26. Alarcón, J.; Cespedes, C.L.; Muñoz, E.; Balbontin, C.; Valdes, F.; Gutierrez, M.; Astudillo, L.; Seigler, D.S. Dihydroagarofuranoid sesquiterpenes as acetylcholinesterase inhibitors from Celastraceae plants: Maytenus disticha and Euonymus japonicus. J. Agric. Food Chem. 2015, 63, 10250-10256. [CrossRef] [PubMed]

27. Perveen, S.; Al-Taweel, A.M.; Fawzy, G.A.; Ibrahim, T.A.; Malik, A.; Khan, A. Cholinesterase inhibitory triterpenes from Perovskia Atriplicifolia. Asian J. Chem. 2014, 26, 6163-6166. [CrossRef]

28. Cespedes, C.L.; Muñoz, E.; Salazar, J.R.; Yamaguchi, L.; Werner, E.; Alarcón, J.; Kubo, I. Inhibition of cholinesterase activity by extracts, fraction and compounds from Calceolaria talcana and C. integrifolia (Calceolariaceae: Scrophuraliaceae). Food Chem. Toxicol. 2013, 62, 919-926. [CrossRef]

29. Xu, W.; Wang, J.; Ju, B.; Lan, X.; Ying, X.; Stien, D. Seven compounds from Portulaca oleracea L. and their anticholinesterase activities. Nat. Prod. Res. 2021, 1-7. [CrossRef]

30. Ul Bari, W.; Rehman, N.U.; Khan, A.; Halim, S.A.; Yuan, Y.; Blaskovich, M.A.T.; Ziora, Z.M.; Zahoor, M.; Naz, S.; Ullah, R.; et al. Bio-Potency and Molecular Docking Studies of Isolated Compounds from Grewia optiva J.R. Drumm. ex Burret. Molecules 2021, 26, 2019. [CrossRef]

31. Onoja, J.O.; Elufioye, T.O.; Sherwani, Z.A.; Ul-Haq, Z. Molecular docking study on columbin isolated from Tinospora cordifolia as a cholinesterase inhibitör. Trop. J. Pharm. Res. 2021, 20, 337-343.

32. Kırmızıbekmez, H.; Erdoğan, M.; Kúsz, N.; Karaca, N.; Erdem, U.; Demirci, F.; Hohmann, J. Secondary metabolites from the aerial parts of Sideritis germanicopolitana and their in vitro enzyme inhibitory activities. Nat. Prod. Res. 2021, 35, 655-658. [CrossRef] [PubMed]

33. Jumeta, K.J.D.; Kagho, D.U.K.; Ateba, J.E.T.; Fotsing, Y.S.F.; Bankeu, J.J.K.; Sewald, N.; Ndjakou, B.L.; Mehreen, L.; Ali, M.S.; Ngouela, A.S. A new cerebroside and bioactive compounds from Celtis adolphi-friderici Engl. (Cannabaceae). Biochem. Syst. Ecol. 2021, 94, 104201. [CrossRef]

34. Othman, A.; Amen, Y.; Shimizu, K. A novel acylated flavonol tetraglycoside and rare oleanane saponins with a unique acetallinked dicarboxylic acid substituent from the xero-halophyte Bassia Indica. Fitoterapia 2021, 152, 104907. [CrossRef]

35. Ślusarczyk, S.; Senol Deniz, F.S.; Abel, R.; Pecio, Ł.; Pérez-Sánchez, H.; Cerón-Carrasco, J.P.; den-Haan, H.; Banerjee, P.; Preissner, R.; Krzyżak, E.; et al. Norditerpenoids with Selective Anti-Cholinesterase Activity from the Roots of Perouskia atriplicifolia Benth. Int. J. Mol. Sci. 2020, 21, 4475. [CrossRef]

36. Saidi, I.; Nimbarte, V.D.; Schwalbe, H.; Waffo-Téguo, P.; Harrath, A.H.; Mansour, L.; Alwasel, S.; Jannet, H.B. Anti-tyrosinase, anti-cholinesterase and cytotoxic activities of extracts and phytochemicals from the Tunisian Citharexylum spinosum L.: Molecular docking and SAR analysis. Bioorg. Chem. 2020, 102, 104093. [CrossRef] [PubMed]

37. Park, J.H.; Whang, W.K. Bioassay-Guided Isolation of Anti-Alzheimer Active Components from the Aerial Parts of Hedyotis diffus and Simultaneous Analysis for Marker Compounds. Molecules 2020, 25, 5867. [CrossRef] 
38. Liu, H.; Li, P.; Bi, L.S.; Wu, W.J.; Yan, H.; He, L.; Qin, X.J.; Liu, H.Y. Polymethylated Phloroglucinol Meroterpenoids from Rhodomyrtus tomentosa and Their Antibacterial and Acetylcholinesterase Inhibitory Effects. Chem. Biodivers. 2020, 17, e2000489. [CrossRef] [PubMed]

39. Xu, K.; Zhou, Q.; Li, X.-Q.; Luo, T.; Yuan, X.-L.; Zhang, Z.-F.; Zhang, P. Cadinane- and drimane-type sesquiterpenoids produced by Paecilomyces sp. TE-540, an endophyte from Nicotiana tabacum L., are acetylcholinesterase inhibitors. Bioorg. Chem. 2020, 104, 104252. [CrossRef]

40. Woo, M.H.; Nguyen, D.H.; Choi, J.S.; Park, S.E.; Thuong, P.T.; Min, B.S.; Le, D.D. Chemical constituents from the roots of Kadsura coccinea with their protein tyrosine phosphatase $1 \mathrm{~B}$ and acetylcholinesterase inhibitory activities. Arch. Pharm. Res. 2020, 43, 204-213. [CrossRef]

41. Harraz, F.M.; Hammoda, H.M.; El-Hawiet, A.; Radwan, M.M.; Wanas, A.S.; Eid, A.M.; ElSohly, M.A. Chemical constituents, Antibacterial and Acetylcholine esterase inhibitory activity of Cupressus macrocarpa leaves. Nat. Prod. Res. 2020, 34, 816-822. [CrossRef] [PubMed]

42. Cao, D.H.; Liao, S.G.; Sun, P.; Xiao, Y.D.; Xiao, C.F.; Hu, H.B.; Weckwerth, W.; Xu, Y.K. Mexicanolide-type limonoids from the twigs and leaves of Cipadessa baccifera. Phytochemistry 2020, 177, 112449. [CrossRef] [PubMed]

43. Cespedes, C.L.; Balbontin, C.; Avila, J.G.; Dominguez, M.; Alarcon, J.; Paz, C.; Burgos, V.; Ortiz, L.; Penaloza-Castro, I.; Seigler, D.S.; et al. Inhibition on cholinesterase and tyrosinase by alkaloids and phenolics from Aristotelia chilensis leaves. Food Chem. Toxicol. 2017, 109, 984-995. [CrossRef] [PubMed]

44. Gasca, C.A.; Castillo, W.O.; Takahashi, C.S.; Fagg, C.W.; Magalhães, P.O.; Fonseca-Bazzo, Y.M.; Silveira, D. Assessment of anti-cholinesterase activity and cytotoxicity of cagaita (Eugenia dysenterica) leaves. Food Chem. Toxicol. 2017, 109, 996-1002. [CrossRef]

45. Karakaya, S.; Koca, M.; Sytar, O.; Duman, H. The natural phenolic compounds and their antioxidant and anticholinesterase potential of herb Leiotulus dasyanthus (K. Koch) Pimenov \& Ostr. Nat. Prod. Res. 2020, 34, 1303-1305. [CrossRef]

46. Min, B.S.; Cuong, T.D.; Lee, J.S.; Shin, B.S.; Woo, M.H.; Hung, T.M. Cholinesterase Inhibitors from Cleistocalyx operculatus Buds. Arch. Pharm Res. 2010, 33, 1665-1670. [CrossRef] [PubMed]

47. Refaey, M.S.; Abdelhamid, R.A.; Elimam, H.; Elshaier, Y.A.M.M.; Ali, A.A.; Orabi, M.A.A. Bioactive constituents from Thunbergia erecta as potential anticholinesterase and anti-ageing agents: Experimental and in silico studies. Bioorg. Chem. 2021, 108, 104643. [CrossRef]

48. Aydin, T. Secondary metabolites of Helichrysum plicatum DC. subsp. plicatum flowers as strong carbonic anhydrase, cholinesterase and $\alpha$-glycosidase inhibitors. Z. Naturforsch. C 2020, 75, 153-159. [CrossRef]

49. Sevindik, H.G.; Güvenalp, Z.; Yerdelen, K.Ö.; Yuca, H.; Demirezer, L.Ö. The discovery of potential anticholinesterase compounds from Achillea millefolium L. Ind. Crop. Prod. 2015, 76, 873-879. [CrossRef]

50. Li, M.; Gao, X.; Lan, M.; Liao, X.; Su, F.; Fan, L.; Zhao, Y.; Hao, X.; Wu, G.; Ding, X. Inhibitory activities of flavonoids from Eupatorium adenophorum against acetylcholinesterase. Pestic. Biochem. Phys. 2020, 170, 104701. [CrossRef]

51. Muhammad, A.; Tel-Cayan, G.; Öztürk, M.; Nadeem, S.; Duru, M.E.; Anis, I.; Ng, S.W.; Shah, M.R. Biologically active flavonoids from Dodonaea viscosa and their structure-activity relationships. Ind. Crop. Prod. 2015, 78, 66-72. [CrossRef]

52. Lee, J.S.; Kim, J.H.; Han, Y.K.; Ma, J.Y.; Kim, Y.H.; Li, W.; Yang, S.Y. Cholinesterases inhibition studies of biological active compounds from the rhizomes of Alpinia officinarum Hance and in silico molecular dynamics. Int. J. Biol. Macromol. 2018, 120, 2442-2447. [CrossRef] [PubMed]

53. Lata, R.; Azizur, R.; Mizanur, R.; Saurav, H. Extraction and in vitro screening of potential acetylcholinesterase, butyrylcholinesterase and BACE1 inhibitors from the leaves of Ocimum sanctum. Indo Am. J. Pharm. Sci. 2017, 4, $2417-2424$.

54. Conforti, F.; Rigano, D.; Menichini, F.; Loizzo, M.R.; Senatore, F. Protection against neurodegenerative diseases of Iris pseudopumila extracts and their constituents. Fitoterapia 2009, 80, 62-67. [CrossRef] [PubMed]

55. Chear, N.J.Y.; Khaw, K.Y.; Murugaiyah, V.; Lai, C.S. Cholinesterase inhibitory activity and chemical constituents of Stenochlaena palustris fronds at two different stages of maturity. J. Food Drug Anal. 2016, 24, 358-366. [CrossRef]

56. Orhan, I.E.; Jedrejek, D.; Senol, F.S.; Salmas, R.E.; Durdagi, S.; Kowalska, I.; Pecio, L.; Oleszek, W. Molecular modeling and in vitro approaches towards cholinesterase inhibitory effect of some natural xanthohumol, naringenin, and acyl phloroglucinol derivatives. Phytomedicine 2018, 42, 25-33. [CrossRef] [PubMed]

57. Kim, J.H.; Lee, S.H.; Lee, H.W.; Sun, Y.N.; Jang, W.H.; Yang, S.Y.; Jang, H.D.; Kim, Y.H. (-)-Epicatechin derivate from Orostachys japonicus as potential inhibitor of the human butyrylcholinesterase. Int. J. Biol. Macromol. 2016, 91, 1033-1039. [CrossRef] [PubMed]

58. Zhang, X.D.; Liu, X.Q.; Kim, Y.H.; Whang, W.K. Chemical constituents and their acetyl cholinesterase inhibitory and antioxidant activities from leaves of Acanthopanax henryi: Potential complementary source against Alzheimer's disease. Arch. Pharm. Res. 2014, 37, 606-616. [CrossRef] [PubMed]

59. Ślusarczyk, S.; Senol Deniz, F.S.; Woźniak, D.; Pecio, Ł.; Pérez-Sánchez, H.; Cerón-Carrasco, J.P.; Stochmal, A.; Alonso, H.H.; Matkowskia, A.; Orhan, I.E. Selective in vitro and in silico cholinesterase inhibitory activity of isoflavones and stilbenes from Belamcandae chinensis rhizoma. Phytochem. Lett. 2019, 30, 261-272. [CrossRef]

60. Liu, Q.; Shen, J.; Li, P.; Li, Y.; He, C.; Xiao, P. Stilbenoids isolated from the roots of Rheum lhasaense under the guidance of the acetylcholinesterase inhibition activity. J. Nat. Med. 2021, 75, 372-380. [CrossRef] 
61. Wahab, S.M.A.; Sivasothy, Y.; Liew, S.Y.; Litaudon, M.; Mohamad, J.; Awang, K. Natural Cholinesterase Inhibitors from Myristica cinnamomea King, Bioorg. Med. Chem. Lett. 2016, 26, 3785-3792. [CrossRef]

62. Sathya, S.; Amarasinghe, N.R.; Jayasinghe, L.; Araya, H.; Fujimoto, Y. Enzyme inhibitors from the aril of Myristica fragrans. S. Afr. J. Bot. 2020, 130, 172-176. [CrossRef]

63. Orhan, I.; Senol, F.S.; Kartal, M.; Dvorská, M.; Zemlicka, M.; Šmejkal, K.; Mokry, P. Cholinesterase inhibitory effects of the extracts and compounds of Maclura pomifera (Rafin.) Schneider. Food Chem. Toxicol. 2009, 47, 1747-1751. [CrossRef] [PubMed]

64. Lee, S.; Youn, K.; Lim, G.T.; Lee, J.; Jun, M. In silico docking and in vitro approaches towards BACE1 and cholinesterases inhibitory effect of citrus flavanones. Molecules 2018, 23, 1509. [CrossRef] [PubMed]

65. Zelík, P.; Lukešová, A.; Čejka, J.; Buděšínský, M.; Havlíček, V.; Čegan, A.; Kopecký, J. Nostotrebin 6, a bis(cyclopentenedione) with cholinesterase inhibitory activity isolated from Nostoc sp. str. Lukešová 27/97. J. Enzym. Inhib. Med. Chem. 2010, 25, 414-420. [CrossRef]

66. Khaw, K.Y.; Choi, S.B.; Tan, S.C.; Wahab, H.A.; Chan, K.L.; Murugaiyah, V. Prenylated xanthones from mangosteen as promising cholinesterase inhibitors and their molecular docking studies. Phytomedicine 2014, 21, 1303-1309. [CrossRef] [PubMed]

67. Saenkham, A.; Jaratrungtawee, A.; Siriwattanasathien, Y.; Boonsri, P.; Chainok, K.; Suksamrarn, A.; Namsa-aid, M.; Pattanaprateeb, P.; Suksamrarn, S. Highly potent cholinesterase inhibition of geranylated xanthones from Garcinia fusca and molecular docking studies. Fitoterapia 2020, 146, 104637. [CrossRef]

68. Seong, S.H.; Ha, M.T.; Min, B.S.; Jung, H.A.; Choi, J.S. Moracin derivatives from Morus radix as dual BACE1 and cholinesterase inhibitors with antioxidant and anti-glycation capacities. Life Sci. 2018, 210, 20-28. [CrossRef]

69. Bhakta, H.K.; Park, C.H.; Yokozawa, T.; Tanaka, T.; Jung, H.A.; Choi, J.S. Potential anti-cholinesterase and b-site amyloid precursor protein cleaving enzyme 1 inhibitory activities of cornuside and gallotannins from Cornus officinalis fruits. Arch. Pharm. Res. 2017, 40, 836-853. [CrossRef]

70. Koay, Y..; Basiri, A.; Murugaiyah, V.; Chan, K.L. Isocorilagin, a Cholinesterase Inhibitor from Phyllanthus niruri. Nat. Prod. Commun. 2014, 9, 515-517. [CrossRef]

71. Tan, W.N.; Khairuddean, M.; Wong, K.C.; Khaw, K.Y.; Murugaiyah, V. New cholinesterase inhibitors from Garcinia atroviridis. Fitoterapia 2014, 97, 261-267. [CrossRef] [PubMed]

72. Stephane, F.F.Y.; Dawe, A.; Fusi, A.A.; Jules, B.K.J.; Ulrich, K.K.D.; Lateef, M.; Bruno, L.N.; Ali, M.S.; Ngouela, S.A. Crotoliganfuran, a new clerodane-type furano-diterpenoid from Croton oligandrus Pierre ex Hutch, Nat. Prod. Res. 2021, 35, 63-71. [CrossRef]

73. Zahoor, M.; Khan, I.; Zeb, A.; Sahibzada, M.U.K.; Naz, S.; Ul Bari, W.; Kamran, A.W. Pharmacological evaluation and in-silico modeling study of compounds isolated from Ziziphus oxyphylla. Heliyon 2021, 7, e06367. [CrossRef]

74. Kwon, Y.; Yang, H.; Chun, W.; Kim, M.J.; Khan, I.A. Two New Pterocarpans from Lespedeza tomentosa. Chem. Nat. Compd. 2021, 57, 451-454. [CrossRef]

75. Liu, L.; Zou, M.; Zeng, K.; Ye, X.; Wang, R.; Wang, W.; Zhang, X. Chemical Constituents and their Antioxidant, Anti-Inflammatory, and Anti-Acetylcholinesterase Activities from Pholidota cantonensis. Plant Foods Hum. Nutr. 2021, 76, 105-110. [CrossRef]

76. Duan, Y.; Yingb, Z.; Zhanga, M.; Yinga, X.; Yang, G. Two new homoisoflavones from Portulaca oleracea L. and their activities. Nat. Prod. Res. 2020, 1-9. [CrossRef]

77. Tomassini, L.; Ventrone, A.; Frezza, C.; Fabbri, A.M.; Fortuna, S.; Volpe, M.T.; Cometa, M.D. Phytochemical analysis of Viburnum davidii Franch. and cholinesterase inhibitory activity of its dihydrochalcones. Nat. Prod. Res. 2020, 1-7. [CrossRef]

78. Rios, M.Y.; Ocampo-Acuña, Y.D.; Ramírez-Cisneros, M.Á.; Salazar-Rios, M.E. Furofuranone Lignans from Leucophyllum ambiguum. J. Nat. Prod. 2020, 83, 1424-1431. [CrossRef]

79. Azman, N.A.N.; Alhawarri, M.B.; Rawa, M.S.A.; Dianita, R.; Gazzali, A.M.; Nogawa, T.; Wahab, H.A. Potential AntiAcetylcholinesterase Activity of Cassia timorensis DC. Molecules 2020, 25, 4545. [CrossRef]

80. Jeong, G.S.; Kang, M.-G.; Lee, J.Y.; Lee, S.R.; Park, D.; Cho, M.; Kim, H. Inhibition of Butyrylcholinesterase and Human Monoamine Oxidase-B by the Coumarin Glycyrol and Liquiritigenin Isolated from Glycyrrhiza uralensis. Molecules 2020, 25, 3896. [CrossRef]

81. Giap, T.H.; Duc, P.M.; The, N.V.; Popova, M.; Bankova, V.; Hue, C.T.; Oanh, V.T.K.; Hang, N.T.M.; Van, H.N.; Le, T.N. Chemical constituents and biological activities of the fruits of Knema pachycarpa de Wilde. Nat. Prod. Res. 2021, 35, 455-464. [CrossRef] [PubMed]

82. Sallam, A.; Mira, A.; Sabry, M.A.; Abdel-Halim, O.B.; Gedara, S.R.; Galala, A.A. New prenylated flavonoid and neuroprotective compounds from Tephrosia purpurea subsp. dunensis. Nat. Prod. Res. 2020, 1-9. [CrossRef] [PubMed]

83. Augustin, N.; Nuthakki, V.K.; Abdullah, M.; Hassan, Q.P.; Gandhi, S.G.; Bharate, S.B. Discovery of Helminthosporin, an Anthraquinone Isolated from Rumex abyssinicus Jacq as a Dual Cholinesterase Inhibitor. ACS Omega 2020, 5, 1616-1624. [CrossRef]

84. Devidas, S.B.; Sendri, N.; Rahmatkar, S.N.; Singh, D.; Bhandari, P. Two undescribed diarylheptanoids from green husk of Carya illinoinensis as acetylcholinesterase inhibitors. Nat. Prod. Res. 2020, 1-9. [CrossRef]

85. Kuanhuta, W.; Aree, T.; Pornpakakul, S.; Sawasdee, P. Novel cucurbitane triterpenoids and anti-cholinesterase activities of constituents from Momordica charantia L. Nat. Prod. Commun. 2014, 9, 765-769. [CrossRef] [PubMed]

86. Orhan, I.E.; Senol, F.S.; Shekfeh, S.; Skalicka-Wozniak, K.; Banoglu, E. Pteryxin-A promising butyrylcholinesterase-inhibiting coumarin derivative from Mutellina purpurea. Food Chem. Toxicol. 2019, 109, 970-974. [CrossRef]

87. Athar, A.M.; Hussain, G.; Aziz-Ur-Rehman; Siddiqui, S.Z.; Ahmad, V.U. In silico study of furanocoumarins from Caryopteris odorata: Moderate inhibitors of butyryl cholinesterase and lipoxygenase. Asian J. Chem. 2017, 29, 758-762. 
88. Wszelaki, N.; Paradowska, K.; Jamroz, M.K.; Granica, S.; Kiss, A.K. Bioactivity-Guided Fractionation for the Butyrylcholinesterase Inhibitory Activity of Furanocoumarins from Angelica archangelica L. Roots and Fruits. J. Agric. Food Chem. 2011, 59, $9186-9193$. [CrossRef] [PubMed]

89. Karakaya, S.; Bingol, Z.; Koca, M.; Dagoglu, S.; Pınar, N.M.; Demirci, B.; Gulcin, I.; Brestic, M.; Sytar, O. Identification of non-alkaloid natural compounds of Angelica purpurascens (Avé-Lall.) Gilli. (Apiaceae) with cholinesterase and carbonic anhydrase inhibition potential. Saudi Pharm. J. 2020, 28, 1-14. [CrossRef]

90. Orhan, I.E.; Deniz, F.S.S.; Salmas, R.E.; Durdagi, S.; Epifano, F.; Genovese, S.; Fiorito, S. Combined molecular modeling and cholinesterase inhibition studies on some natural and semisynthetic O-alkylcoumarin derivatives. Bioorg. Chem. 2019, 84, 355-362. [CrossRef] [PubMed]

91. Güvenalp, Z.; Özbek, H.; Yerdelen, K.Ö.; Yılmaz, G.; Kazaz, C.; Demirezer, L.Ö. Cholinesterase inhibition and molecular docking studies of sesquiterpene coumarin ethers from Heptaptera cilicica. Rec. Nat. Prod. 2017, 11, 462-467. [CrossRef]

92. Senol, F.S.; Skalicka-Wozniak, K.; Khan, M.T.H.; Orhan, I.E.; Sener, B.; Glowniak, K. An in vitro and in silico approach to cholinesterase inhibitory and antioxidant effects of the methanol extract, furanocoumarin fraction, and major coumarins of Angelica officinalis L. Fruits. Phytochem. Lett. 2011, 4, 462-467. [CrossRef]

93. Kashyap, P.; Ram, H.; Shukla, S.D.; Kumar, S. Scopoletin: Antiamyloidogenic, Anticholinesterase, and Neuroprotective Potential of a Natural Compound Present in Argyreia speciosa Roots by In Vitro and In Silico Study. Neurosci. Insights 2020, 15, 1-10. [CrossRef]

94. Dastan, D.; Validi, S.; Ebadi, A. Kamonolol acetate from Ferula pseudalliacea as AChE inhibitor: In vitro and in silico studies. Struct. Chem. 2020, 31, 965-973. [CrossRef]

95. Heo, J.H.; Eom, B.H.; Ryu, H.W.; Kang, M.-G.; Park, J.E.; Kim, D.-Y.; Kim, J.-H.; Park, D.; Oh, S.-R.; Kim, H. Acetylcholinesterase and butyrylcholinesterase inhibitory activities of khellactone coumarin derivatives isolated from Peucedanum japonicum Thurnberg. Sci. Rep. 2020, 10, 21695. [CrossRef]

96. Khan, D.; Zhao, W.; Ahmad, S.; Khan, S. New antioxidant and cholinesterase inhibitory constituents from Lonicera quinquelocularis. J. Med. Plant. Res. 2014, 8, 313-317.

97. Elufioye, T.O.; Obuotor, E.M.; Agbedahunsi, J.M.; Adesanya, S.A. Cholinesterase inhibitory activity and structure elucidation of a newphytol derivative and a new cinnamic acid ester from Pycnanthus angolensis. Rev. Brasil. Farmacog. 2016, 26, 433-437. [CrossRef]

98. Huang, J.; Lu, X.Q.; Lu, J.; Li, G.Y.; Wang, H.Y.; Li, L.H.; Lin, R.C.; Wang, J.H. Two new phthalides with BuChE inhibitory activity from Ligusticum chuanxiong. J. Asian Nat. Prod. Res. 2013, 15, 1237-1242. [CrossRef] [PubMed]

99. Choi, Y.H.; Choi, C.W.; Kim, J.K.; Jeong, W.; Park, G.H.; Hong, S.S. (-)-Pteroside N and pterosinone, new BACE1 and cholinesterase inhibitors from Pteridium aquil. Phytochem. Lett. 2018, 27, 63-68. [CrossRef]

100. Taş, M.; Küçükaydın, S.; Tel-Çayan, G.; Duru, M.E.; Öztürk, M.; Türk, M. Chemical constituents and their bioactivities from truffle Hysterangium infatum. J. Food Meas. Charact. 2021. [CrossRef]

101. Moriou, C.; Lacroix, D.; Petek, S.; El-Demerdash, A.; Trepos, R.; Leu, T.M.; Florean, C.; Diederich, M.; Hellio, C.; Debitus, C.; et al. Bioactive Bromotyrosine Derivatives from the Pacific Marine Sponge Suberea clavata (Pulitzer-Finali, 1982). Mar. Drugs 2021, 19, 143. [CrossRef] [PubMed]

102. Alqahtani, Y.S. Bioactive stigmastadienone from Isodon rugosus as potential anticholinesterase, $\alpha$-glucosidase and COX/LOX inhibitor: In-vitro and molecular docking studies. Steroids 2021, 172, 108857. [CrossRef] [PubMed]

103. Liu, L.; Yin, Q.M.; Gao, Q.; Li, J.; Jiang, Y.; Tu, P.F. New biphenanthrenes with butyrylcholinesterase inhibitory activitiy from Cremastra append. Nat. Prod. Res. 2021, 35, 750-756. [CrossRef] [PubMed]

104. Boudjada, A.; Touil, A.; Bensouici, C.; Bendif, H.; Rhouati, S. Phenanthrene and dihydrophenanthrene derivatives from Dioscorea communis with anticholinesterase, and antioxidant activities. Nat. Prod. Res. 2019, 33, 3278-3282. [CrossRef] [PubMed]

105. Liu, X.; Wu, H.; Tao, X.; Ying, X.; Stien, D. Two amide glycosides from Portulaca oleracea L. and its bioactivities. Nat. Prod. Res. 2021, 35, 2655-2659. [CrossRef] [PubMed]

106. Tel-Çayan, G.; Muhammad, A.; Deveci, E.; Duru, M.E.; Öztürk, M. Isolation, structural characterization, and biological activities of galactomannans from Rhizopogon luteolus and Ganoderma adspersum mushrooms. Int. J. Biol. Macromol. 2020, 165, $2395-2403$. [CrossRef] [PubMed]

107. do Nascimento, B.O.; da Silva Neto, O.C.; Teodoro, M.T.F.; de Oliveira Silva, E.; Guedes, M.L.S.; David, J.M. Macrolobin: A new unusual C-glycoside chromone from Macrolobium latifolium and its anticholinesterase and antimicrobial activities. Phytochem. Lett. 2020, 39, 124-127. [CrossRef]

108. Lawal, B.A.; Udobre, A.; Elufioye, T.O.; Ahmadu, A.A.; Olanipekun, B. Novel cholinesterase inhibitory effect of $\alpha$-spinasterol isolated from the leaves of Acacia auriculiformis A. CUNN Ex. Benth (Fabaceae). Trop. J. Pharm. Res. 2020, 19, 1473-1479. [CrossRef]

109. Yao, C.P.; Li, J.; Liu, J.F.; Zou, Z.X.; Kang, F.H.; Li, X.M.; Li, D.; Xu, K.P.; Xu, P.S.; Tan, G.S. Seladelicatulasine A-G, C27 steroidal glycosides with cholinesterase inhibitory activities from Selaginella delicatula. Phytochemistry 2020, 180, 112514. [CrossRef]

110. Liu, H.; He, X.Z.; Feng, M.Y.; Yuan-Zeng.; Rauwolf, T.J.; Shao, L.D.; Ni, W.; Yan, H.; Porco, J.A., Jr.; Hao, X.J.; et al. cylphloroglucinols with acetylcholinesterase inhibitory effects from the fruits of Eucalyptus robusta. Bioorg. Chem. 2020, $103,104127$. [CrossRef]

111. Yang, N.N.; Ma, Q.Y.; Kong, F.D.; Xie, Q.Y.; Dai, H.F.; Zhou, L.M.; Yu, Z.F.; Zhao, Y.X. Napthrene Compounds from Mycelial Fermentation Products of Marasmius berteroi. Molecules 2020, 25, 3898. [CrossRef] 
112. Dai, L.-Y.; Yin, Q.-M.; Qiu, J.-K.; Zhang, Z.-Y.; Li, G.; Huang, M.-N.; Liu, L. Goodyschle A, a new butenolide with significant BchE inhibitory activity from Goodyera schlechtendaliana. Nat. Prod. Res. 2020, 1-6. [CrossRef] [PubMed]

113. Dai, Y.; Li, K.; She, J.; Zeng, Y.; Wang, H.; Liao, S.; Lin, X.; Yang, B.; Wang, J.; Tao, H.; et al. Lipopeptide Epimers and a Phthalide Glycerol Ether with AChE Inhibitory Activities from the Marine-Derived Fungus Cochliobolus lunatus SCSIO41401. Mar. Drugs 2020, 18, 547. [CrossRef] [PubMed]

114. Zhang, Y.F.; Yang, Z.D.; Yang, X.; Yang, L.J.; Yao, X.J.; Shu, Z.M. Two new compounds, Talaromycin A and B, isolated from an endophytic fungus, Talaromyces aurantiacus. Nat. Prod. Res. 2020, 34, 2802-2808. [CrossRef] [PubMed]

115. Lou, H.; Yi, P.; Hu, Z.; Li, Y.; Zeng, Y.; Gu, W.; Huang, L.; Yuan, C.; Hao, X. Polycyclic polyprenylated acylphloroglucinols with acetylcholinesterase inhibitory activities from Hypericum perforatum. Fitoterapia 2020, 143, 104550. [CrossRef]

116. Aftab, Z.; Bushra; Khan, H.; Khan, D.F.; Khan, A.; Ullah, H.; Shahnaz; Khan, S. Three New Cholinesterase Inhibitory Cassioates from Cassia Fistula. Pharm. Chem. J. 2020, 53, 1069-1075. [CrossRef]

117. Loizzo, M.R.; Tundis, R.; Menichini, F.; Menichini, F. Natural Products and their Derivatives as Cholinesterase Inhibitors in the Treatment of Neurodegenerative Disorders: An Update. Curr. Med. Chem. 2008, 15, 1209-1228. [CrossRef]

118. Thapa, P.; Upadhyay, S.P.; Suo, W.Z.; Singh, V.; Gurung, P.; Lee, E.S.; Sharma, R.; Sharma, M. Chalcone and its analogs: Therapeutic and diagnostic applications in Alzheimer's disease. Bioorg. Chem. 2021, 108, 104681. [CrossRef]

119. Perry, N.S.L.; Houghton, P.J.; Theobald, A.; Jenner, P.; Perry, E.K. In-vitro inhibition of human erythrocyte acetylcholinesterase by salvia lavandulaefolia essential oil and constituent terpenes. J. Pharm. Pharmacol. 2000, 52, 895-902. [CrossRef]

120. Wong, K.K.; Ngo, J.C.; Liu, S.; Lin, H.Q.; Hu, C.; Shaw, P.; Wan, D.C. Interaction study of two diterpenes, cryptotanshinone and dihydrotanshinone, to human acetylcholinesterase and butyrylcholinesterase by molecular docking and kinetic analysis. Chem. Biol. Interact. 2010, 187, 335-339. [CrossRef] [PubMed]

121. Miyazawa, M.; Yamafuji, C. Inhibition of acetylcholinesterase activity by bicyclic monoterpenoids. J. Agric. Food Chem. 2005, 53, 1765-1768. [CrossRef]

122. Szwajgier, D.; Baranowska-Wójcik, E. Terpenes and Phenylpropanoids as Acetyl- and Butyrylcholinesterase Inhibitors: A Comparative Study. Curr. Alzheimer Res. 2019, 16, 963-973. [CrossRef]

123. Wojtunik-Kulesza, K.; Rudkowska, M.; Kasprzak-, K.; Oniszczuk, A.; Borowicz-Reutt, K. Activity of Selected Group of Monoterpenes in Alzheimer's Disease Symptoms in Experimental Model Studies-A Non-Systematic Review. Int. J. Mol. Sci. 2021, $22,7366$. [CrossRef]

124. Szwajgier, D.; Baranowska-Wojcik, E.; Borowiec, K. Phenolic Acids Exert Anticholinesterase and Cognition-Improving Effects. Curr. Alzheimer Res. 2018, 15, 531-543. [CrossRef] [PubMed]

125. Szwajgier, D.; Borowiec, K.; Pustelniak, K. The Neuroprotective Effects of Phenolic Acids: Molecular Mechanism of Action. Nutrients 2017, 9, 477. [CrossRef] [PubMed]

126. Jabir, N.R.; Khan, F.R.; Tabrez, S. Cholinesterase targeting by polyphenols: A therapeutic approach for the treatment of Alzheimer's disease. CNS Neurosci Ther. 2018, 24, 753-762. [CrossRef] [PubMed]

127. Roseiro, L.B.; Rauter, A.P.; Serralheiro, M.L.M. Polyphenols as Acetylcholinesterase Inhibitors: Structural Specificity and Impact on Human Disease. Nutr. Aging 2012, 1, 99-111. [CrossRef]

128. Bag, S.; Ghosh, S.; Tulsan, R.; Sood, A.; Zhou, W.; Schifone, C.; Foster, M.; LeVine, H.; Török, B.; Török, M. Design, synthesis and biological activity of multifunctional $\alpha, \beta$-unsaturated carbonyl scaffolds for Alzheimer's disease. Bioorg. Med. Chem. Lett. 2013, 23, 2614-2618. [CrossRef]

129. de Souza, L.G.; Renna, M.N.; Figueroa-Villar, J.D. Coumarins as cholinesterase inhibitors: A review. Chem. Biol. Interact. 2016, 254, 11-23. [CrossRef]

130. Santos, T.C.; Gomes, T.M.; Pinto, B.A.S.; Camara, A.L.; Paes, A.M.A. Naturally Occurring Acetylcholinesterase Inhibitors and Their Potential Use for Alzheimer's Disease Therapy. Front. Pharmacol. 2018, 9, 1192. [CrossRef] 